レーザーオリジナル

\author{
太陽励起レーザーの開発と宇宙空間における \\ レーザーエネルギー伝送への応用 \\ 湯上 浩雄 $*$ ・内藤 均 $*$ 嵐 治夫 $*$
}

（1996 年9月 2 日 受理)

\title{
Development of Solar-Pumped Lasers and its Application to Laser Power Beaming in Space
}

\author{
Hiroo YUGAMI*, Hitoshi NAITO* and Haruo Arashi*
}

(Received September 2, 1996)

\begin{abstract}
Power transmission by high power lasers is one of the most attractive methods for energy supply system in space. This paper describes the results of solar-pumped solid state lasers developed by the author's group, and some concepts of laser power beaming proposed in USA and Japan. Finally, we introduce the proposal on the space experiment of laser power beaming at Japanese Experiment Module (JEM) on the space station.
\end{abstract}

Key Words: Solar-pumped laser, Laser power beaming, Solar energy conversion, Laser propulsion, Space, Energy transmission

\section{1.はじめに}

21 世紀においては，宇宙環境を利用した宇宙 産業の発展や月面ステーションなどの建設が期 待される。1994年の宇宙開発委員会長期ビジョ ン懇談会では，宇宙インフラストラクチャーの 展開として, 燃料ステーションと次世代宇宙ス テーションを中心に低中高度軌道 (Low Earth Orbit: LEO) や静止軌道 (Geostationary Earth Orbit: $\mathrm{GEO})$ 上にある人工衛星などを支援するシステム を想定している1)。
このような, 高度な宇宙活動を可能にするた めには，高効率なエネルギー生産と供給を行う システムが不可欠である。このためのシステム として, 幾つかのパワーステーションで, 太陽 光からレーザー光への変換を行い, 個々のユー ザヘレーザーでエネルギーを伝送することが考 えられている。このシステムの利点としては, 個々のユーザーが巨大な太陽電池を装備する必 要が無く, システムの簡単化と軽量化が可能と なり，宇宙への輸送コストや保守の簡素化が可 能となることが挙げられる。

* 東北大学工学部機械知能工学科（９ 980-77 仙台市青葉区荒巻字青葉）

* Faculty of Engineering, Tohoku University (Aramaki, Aoba-ku, Sendai 980-77) 
したがって、軽量, 高効率で、安定的に太陽 エネルギーをレーザー光へ変換し，長距離の伝 送が可能なシステムの開発が、本格的宇宙利用 において重要と考えられている。

また，このような宇宙ステーションー人工衛 星などのSpace-to-Space以外にも，地上での工ネ ルギー消費量の増大や地球環境保全に対応する ために，宇宙や月面でのエネルギー生産と地上 へのエネルギー伝送が考えられる。

我々は，太陽エネルギー利用の高度化に関す る研究の一環として, 太陽光励起レーザーの研 究を行っている。本文では, 太陽光直接励起固 体レーザーの研究状況について述べた後, 宇宙 でのレーザーエネルギー伝送構想を幾つか紹介 し, 最後に, 国際宇宙ステーションでのレー ザーエネルギー伝送実験について述べる。

\section{2. 太陽光直接励起固体レーザーの研究}

宇宙でのエネルギー伝送を目的に, 太陽を1次 エネルギーとした種々のレーザーに関する多く の研究が報告されている2-6)。それぞれのレー ザーで長所, 短所が有るが, 太陽光からレー ザー光への変換効率では, 太陽電池により発電 した電力を用いた太陽光間接励起型レーザーで ある半導体レーザー (Laser Diode: LD) アレイや LD励起固体レーザーが最も高い。これに対し て, 大型の太陽集光器を用いた太陽光直接励起 固体レーザーは, 軌道上でのシステムの重量が 最も軽くできる特長が有る。このことから, 太 陽集光器を用いた太陽光励起レーザーの研究

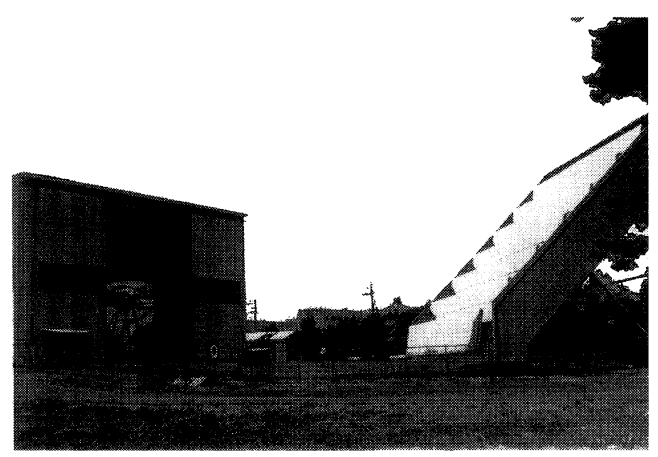

Fig. 1 A large solar concentrator and a heliostat.

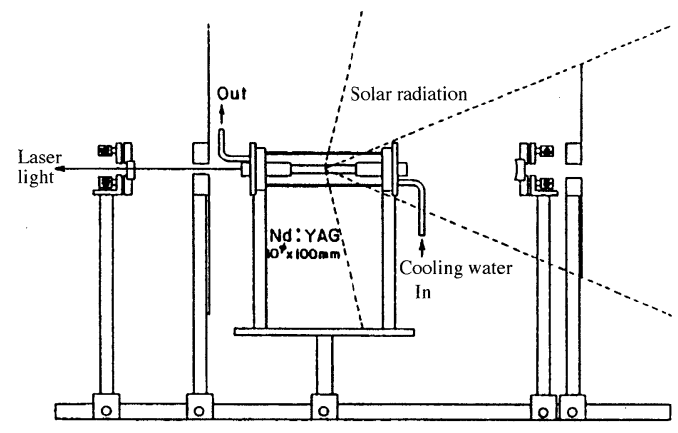

Fig. 2 Experimental setup of a solar-pumped Nd:YAG laser.

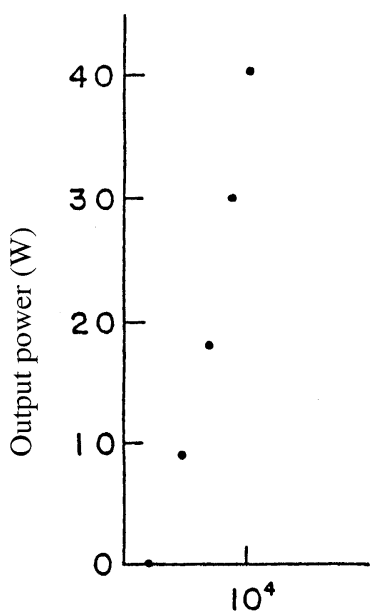

Concentration ratio

Fig. 3 Output of solar-pumped Nd:YAG vs. concentration tario of solar radiation.

は，1966年にC. G. Young7) が初めて発振に成功し て以来, 幾つかの研究グループにより精力的に 行なわれてきた8-12)。

我々は, ヘリオスタット方式の大型太陽集光 器(Fig. 1)を用いてNd:YAGレーザーを用いた太 陽光励起レーザーの研究を行っている13)。放物 面鏡は口径 $10 \mathrm{~m}$ ，焦点距離 $3.2 \mathrm{~m}$ で181枚のモザイ ク鏡からなっている。この集光器の太陽集中度 (地上での直達太陽日射パワー密度に対する集光 器焦点位置でのパワー密度の比) は平面試料で5.1 $\times 10^{4}$ である。

Fig. 2に太陽光励起Nd:YAGレーザーの実験装 置を示す。本装置ではレーザー結晶の周囲から 
均等に高密度太陽光が入射するように, レー ザーロッドの軸を太陽集光器の光軸に平行にし てある。レーザーロッドは, 直径 $10 \mathrm{~mm}$, 長さ $100 \mathrm{~mm}, \mathrm{Nd}^{3+}$ 濃度が $0.9 \%$ ものを用いた。太陽 集光器に入射する太陽光量を, 絞りを用いて変 化させながら，レーザー出力を測定した結果を Fig. 3に示す。しきい値以上では, 入射光量に比 例してレーザー出力が増大していることがわか る。この実験では, マルチモードで40Wのレー ザー出力が得られた。この時の, 太陽エネル ギーのレーザー光への変換効率は約 $1.6 \%$ であっ た。

この太陽集光器により作られる焦平面での太 陽像は直径約 $30 \mathrm{~mm}$ の円形であり，レーザーロッ ドとの形状の一致が悪く, 太陽光の利用率の低 下の問題が生じる。この問題点を低減すると同 時に, 太陽集中度を上げるために, 2次集光器と して非結像光学の理論に基づいて作製したCPC (Compound Parabolic Concentrator) と呼ばれる集光 器を用いてレーザーロッドの励起を行った ${ }^{14)}$ 。

Fig. 4は作製したCPCの断面図とロッド $\left(4 \mathrm{~mm}^{\phi}\right)$ との位置関係を示している。CPCの紙面垂直方向 の長さは $6 \mathrm{~cm}$ である。材質は真鍮性で, 表面は金 コーテングされている。

$\mathrm{CPC}$ では, 許容角 $\theta_{\mathrm{a}}$ より小さな角度で入射した光 は, すべてロッドに到達し, ロッドを均一に励 起することができる。本実験では， $\theta_{\mathrm{a}}$ は太陽集光 器のリム角 $53^{\circ}$ と一致するように設計されてい る。

円筒形状のターゲットに対するCPCの入射口 の最大幅は, $2 \pi a / \sin \theta_{\mathrm{a}}$ で与えられる( $a$ はロッドの 半径)。従って本実験では, 入射口の最大幅は

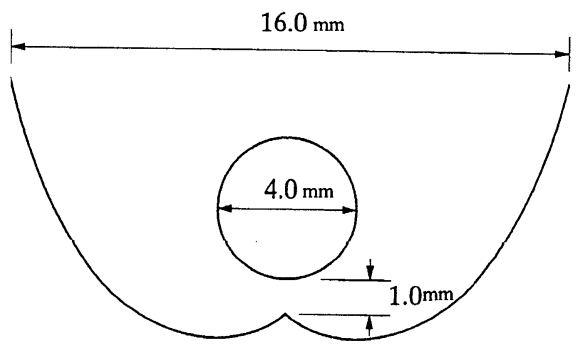

Fig. 4 Cross-sectional view of the Compound Parabolic Concentrator (CPC) used in the experiment.
$15.7 \mathrm{~mm}$ となり，レーザーロッドの有効吸収面積 が，CPCを用いることにより，4mm×6cm から， $16 \mathrm{~mm} \times 6 \mathrm{~cm}$ に増加する。実際に太陽光を用いて 発振実験を行ったところ, 同じ太陽光強度のと きに，5倍の出力を得た。太陽光の有効吸収面積 比以上の出力差があるのは, CPCにより均一光励 起されたことにより熱レンズ効果などが低下し たことによると考えられる。

CPCを2次集光器として用いることにより，1 次集光器で円形に結像した太陽イメージをより 効率的にレーザロッドに集光で，集中太陽光の 利用率を向上することが出来た。しかしなが ら，レーザロッドに入射した太陽光強度から計 算した変換効率は $1.6 \%$ でり，今後の課題とし て太陽光ーレーザー光变換の高効率化を行うこ とが不可久である。

太陽光スペクトルを分割して利用することに よる太陽光直接励起型レーザーの高効率化がイ スラエルのグループ12)により提案されている。 彼らの計画では, 太陽光を4つの領域に分割し, 可視光をアレキサンドライトレーザーに, 近赤 外光をNd:YAGレーザーの励起にそれぞれ用い, 他の領域の光を太陽電池や熱デバイスによる発 電用として用いる。

ドイツ航空宇宙研究所では, Fig. 5に示すよう な太陽光励起レーザーとソーラーダイナミック システムを組み合わせた軌道上システムを提案 している15)。このシステムでは, 全太陽光スペ クトルの38\%(400-700nm)を用いて全太陽光スペ クトルに対する変換効率 $8 \%$ で太陽光ーレーザー 光変換が可能であるとしている。さらに, 残り の62\%の太陽スペクトルをソーラーダイナミック

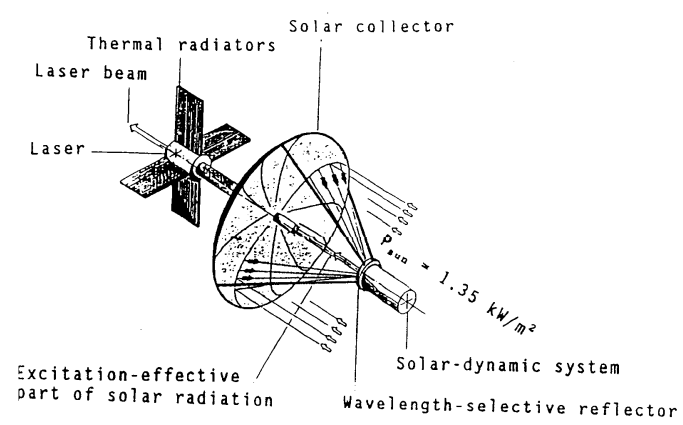

Fig. 5 Space-based solar laser system. 
システムにより効率30\%で電力に変換できること から，全太陽光スペクトルに対するソーラーダ イナミックシステムの効率は $19 \%$ となる。従っ て，入射太陽エネルギーに対するレーザー光お よび電力への変換効率はシステム全体で $27 \%$ に達 するとしている。ただし，8\%の太陽光ーレー ザー光変換を達成するためには，レーザー媒質 の冷却を効率良く行い, 熱負荷を低減する必要 が有る。また，このシステムでは発生した電力 は主に軌道上システムの維持に使われるが, 余 剩電力を用いてLD励起固体レーザーを発振てさ せることにより, 太陽光ーレーザー光変換効率 を上げることが可能である。

このように, 太陽光直接励起レーザーは本質 的には高効率を得られる可能性があるが，レー ザー媒質の熱負荷を低減することが大きな課題 となっている。我々は, 熱負荷の低減を目的と して最近, 太陽電池を用いた太陽光間接励起LD レーザーの開発を始めており, 太陽光直接励起 レーザーと組み合わせることにより,より高効率 なシステムの構築を目指している16)。

\section{3. 宇宙でのレーザーエネルギー伝送構想}

\section{1 軌道上へのエネルギー伝送}

人工衛星を用いた通信や観測へのニーズは今 後益々増大すると考えられる。したがって，人 工衛星の打ち上げや維持コストの削減と寿命の 延長が要求されている。このため, レーザーに よる電力供給やレーザー推進に関する構想があ る。このような概念にもとづくレーザーエネル ギー伝送は，大気による影響が有る高度 $300 \mathrm{~km}$ 下のLEOにある人工衛星に対して，太陽電池よ り経済的であると試算されている17)。

米国NASAのYoungら ${ }^{18)}$ は, Fig. 6に示すような 軌道上 $6400 \mathrm{Km}$ にある太陽光励起レーザー・パ ワーステーションからのエネルギー伝送によ り，LEOにある人工衛星へのエネルギー供給を 提案している。彼らは, $148000 \mathrm{~m}^{2}$ の太陽集光器 を用いて沃素レーザーにより1MWの出力を出す 太陽光励起レーザーを構築し, $11,000 \mathrm{~km}$ 先で $1 \mathrm{~m}$ に集光できる伝送光学系を考えている。このシ ステムでは，レーザー媒質 $\left(t-\mathrm{C}_{4} \mathrm{~F}_{9} \mathrm{I}\right)$ を補給する

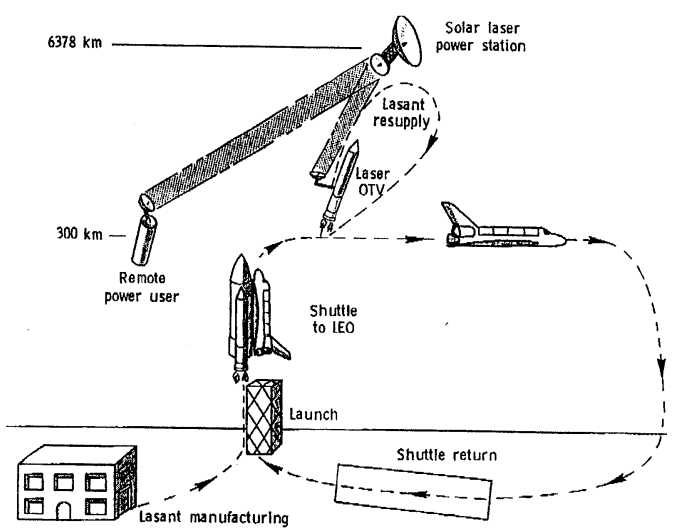

Fig. 6 Schematic diagram for solar-pumped laser system. The molecules of the gaseous lasant $\left(\mathrm{t}-\mathrm{C}_{4} \mathrm{~F}_{9} \mathrm{I}\right)$ is supplied by laser Orbit Transfer Vehicle (OTV).

必要が有り，シャトルによりLEOまで運ばれた ロケットを，レーザー推進によりパワーステー ションまで運搬するためのエネルギー供給を行 うシステムを提案している。

これは，軌道上にあるパワーステーションか ら人工衛星へのレーザーエネルギー伝送を提案 したものであるのに対し, 地上設置のレーザー サイトから人工衛星にエネルギーを送るSELENE 計画がアメリカで提案されている19)。この計画 では, 地上設置の自由電子レーザー光を補償光 学系によりLEOにある人工衛星に照射し, 太陽 電池へのエネルギー供給や，食の間のエネル ギー供給を目指している。また，軌道上にある Orbit Transfer Vehicle (OTV)に電力を供給し，電 気推進によりLEOに打ち上げられた人工衛星を OTVでGEOまで引き上げる構想を持っている。 彼らは, これらのシステムは近い将来, 採算性 が有るとしている。

\section{2 地上へのレーザーエネルギー伝送}

今後, 飛躍的に増大する地球上のエネルギー 需要と, 環境負荷の軽減に対応するために宇宙 発電衛星 (Space Power Satellite: SPS) や月面基地 で発電した電力を地上に伝送し利用するLunar Energy Park (LEP) 計画20) (Fig. 7) が考えられてい る。Glaser ${ }^{21}$ により1968年にSPSからのマイクロ 波電力伝送システムが提案されて以来, マイク 


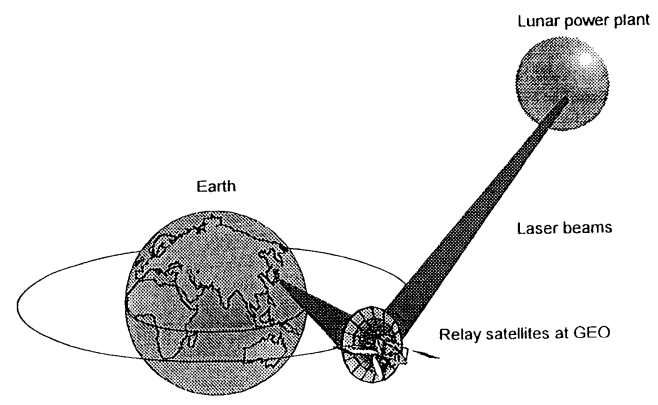

Fig. 7 Laser power transmission from moon to earth for Lunar Energy Park (LEP).

ロ波によるエネルギー伝送に関する研究が世界 で数多くなされ，システム研究はレーザー伝送 と比較すると非常に進んでいる。マイクロ波の 特長は高変換効率と大気の透過性が高いことで ある。これに対しレーザー伝送では回折広がり が小さく送受信光学系を小さくできる特長が有 る。波長 $\lambda$, 口径Dのレーザー光が距離 $d$ 伝搬した 後のAiryディスクの口径: $D m$ は, $D m=2.44 d \lambda / D$ で 与えられ，マイクロ波に比べて2桁以上送受信施 設を小さくできることが分かる。

レーザー光は大気層での吸収による減衰があ るが, $\mathrm{CO}_{2}$ レーザーの $10 \mu \mathrm{m}$ 帯を用いれば70-80\% の透過率が期待できる。また，生体への影響を 考慮した最大許容露光量が $\mathrm{CO}_{2}$ レーザーを用いた 場合マイクロ波のそれより20倍高くできる。以 上のことから, 特に, 月面ステーションからの エネルギー伝送を考たときは，レーザー伝送が 優位と考えられている22)。

日本で発案されたLEP計画では，フェーズAと して500kWeの太陽集熱発電システムを月面上に 設置し、レーザーエネルギー伝送の実証試験を 行い, フェーズB, Cには原子力発電所を建設し, それぞれ40MWe, 100GWeの電力を地上に伝送す る構想である23)。

4. 国際宇宙ステーションでのレーザーエネル ギー伝送実験

現在, 国際共同で宇宙ステーションの建設が 計画さてれおり, 我が国では, 宇宙開発事業団 (National Space Development Agency of Japan: NASDA)が日本実験モジュール（Japanese Experi-

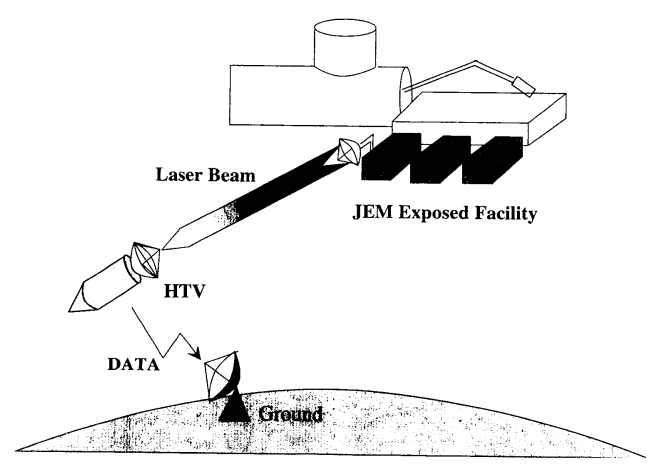

Fig. 8 Schematic diagram for the experiment of laser power transmission to H2 Transfer Vehicle (HTV) from Japanese Experiment Module (JEM) on the space station.

ment Module: JEM)の建設を行っている。JEMに は, 予圧部と宇宙空間に露出した曝露部があ る。東北大学々科学技術庁航空宇宙技術研究所 (National Aerospace Laboratory: NAL) とが中心と なり，このJEM曝露部の1ポートを用いてFig. 8に 示すようなレーザーによるエネルギー伝送の実 証案験を提案している。

$\mathrm{JEM}$ 曝露部のペイロードには大きさと重量の 制限があることから, 大型の太陽集光器を用い た実験は困難であることと, 熱負荷の観点か ら, 本計画ではステーションからの電力を用い てレーザーを発振させるシステムを考えてい る。レーザーとしては重量とシステムの安定性 から, 全固体レーザーであるLD励起固体レー ザー(Diode Pumped Solid State Laser:DPSSL)を用 いる。LDレーザー自身を用いるほうが効率は高 いが指向性で問題があり, 現時点では, 宇宙で の超長距離伝送にはDPSSLまたはDPSSLのSHG を用いるのが最適であると考えられる。しか し, LDアレイの位相整合技術が発展すれば, 将 来的にはLDによるエネルギー伝送が実用化され ると考えられる。

レーザー出力に関しては, 使用できる電源容 量や排熱量に制限があるが，エネルギー伝送の 実証として意味の有るレーザー出力で実験を行 う必要が有る。今後のレーザー技術の進展によ るが, 現段階では, DPSSLの2倍波で平均出力 $100 \mathrm{~W}(1 \mathrm{kHz})$ を目標としている。

受光ターゲットとしては, テスト用の人工衛 
星または, JEMから切り離された後のH2Transfer Vehicle (HTV)を想定しており，伝送距離は 50$100 \mathrm{~km}$ を目標としている。受光側口径はできる限 り小さくする必要が有り, 指向精度としては6$7 \mu \mathrm{rad}$ 程度が必要である。

また, 曝露部でのレーザーシステムでは, 固 体レーザーとLDの非液体冷却方式を開発する必 要が有る。宇宙空間では放射により排熱を行う が，LDは低温度で大量の熱を放出するため，ラ ジエターやヒートパイプなどの開発が必要であ る。このほかにも, 光学素子の安定化や無重 力・真空中でのオートアライメント機構の開発 などが必要であると考えられる。

受光器としては, 光電セルによる光電変換を 想定している。単色光に対するセルの変換効率 は太陽光に対するものより高く, 理論的には YAGの基本波に対して $60 \%$ ，SHGに対して $80 \%$ 程度の変換効率が期待できる24)。しかしなが ら, 現状の太陽電池では $0.5 \mu \mathrm{m}$ の光に対して約 $30 \%(\mathrm{GaAs})$ ，および約20\% $(\mathrm{Si})$ の変換効率であ る。更に，パルス光に対しては更に効率が低下 することが知られており25)，レーザーエネル ギー伝送の効率を改善するためには光電セルの 開発が必要不可欠である。NASA, Lewis研究所 ではSiやGaAsセルのパルス光照射時の特性につ いての実験やシミュレーションが行なわれてい る26)。

宇宙ステーションのJEMの運用開始は2002年 が予定されている。従って, この計画が採択さ れた場合, 今後8-10年以内にミッションが開始さ れる可能性が高い。

現在, NALの角田宇宙推進技術研究センター (宮城県)においてNALと東北大学を中心に, 住 友重機械工業(株)の協力を得て, レーザーエネ ルギー伝送の地上実験が開始されている。今 後, より長距離間の伝送や航空機を用いた実験 を行い, 各要素技術の開発指針や技術課題の抽 出を精力的に行う必要がある。

\section{5. まとめ}

宇宙空間でのレーザーエネルギー伝送に関連 して太陽光励起レーザーの研究の現状や, レー
ザーエネルギー伝送構想について述べた。宇宙 での高出カレーザーの研究は軍事技術と密接に 連携して開発が進んできたが, 冷戦終結後, ア メリカやロシアで蓄積されたこの分野での技術 が，民生用として転用されてきおり，今後 21 世 紀初頭には，レーザーエネルギー伝送が実用化 される可能性があると考えられる。日本では， レーザーエネルギー伝送に関して関心がある研 究者は多くないように感じられる。しかし，こ こで紹介した国際宇宙ステーションでの実験な どは, 少数の研究者のみで実現することは当然 不可能であり, レーザー光源開発はもとより, 太陽エネルギー変換, 受光素子, 宇宙構造物, システム設計などの分野の研究者からなる研究 組織を形成する必要が有り, 多くの研究者が レーザーエネルギー伝送に興味を持っていただ けることを期待する。

\section{参 考 文 献}

1) 宇宙開発委員会長期ビジョン懇談会 (1994年 7月).

2) E. W. Walbridge: Space Solar Power Rev. 3 (1982) 45.

3) R. J. De Young, J. H. Lee, M. D. Williams and G. Schuster, E. J. Conway: NASA TM-4045 (1988).

4) K. Maeno, H. Aoyama, Y. Hanaoka and H. Arashi: 7th Int. Symp. on Gas Flow \& Chemical Lasers (GCL) 22 (1988).

5) M. Weksler and J. Shwartz: IEEE J. Quantum Electron. QE-24 (1988) 1222.

6) U. Brauch, H. Opower, W. Wittwer and J. Muckenschnabel: Proc. SPS'91 (1991) 320.

7) C. G. Young: Appl. Opt. 5 (1966) 993.

8) H. Arashi and M. Ishigame: J. Space Tech. and Sci. 1 (1986) 23.

9) R. Winston: Science, March (1991) 52.

10) K. H. Kim, D. D. Venable, L. A. Brown and H. Lee: J. Appl. Phys. 69 (1991) 2841.

11) U. Brauch, J. Muckenschnabel, G. A. Thompson, H. Bernstein, A. Yogev, A. Reich and M. Oron: Opt. Eng. 31 (1992) 1072.

12) V. Krupkin, Y. Kagan and A. Yogev: Proc. SPIE 
38th Int. Symp. on Optical Applied Science and Eng. (1993).

13) H. Arashi, H. Yugami and H. Naito: WPT-95 (Kobe, Japan Oct. 16-19, 1995).

14) H. Arashi, D. Cooke and H. Naito: Jpn. J. Appl. Phys. 34 (1995) 4795.

15) U. Brauch, W. Schall, G. Spindler, W. Wittwer and E. Zeyfang: ESA-TT-1246 (1991).

16）湯上浩雄, 内藤 均, 嵐 治夫：第15回宇宙 エネルギーシンポジウム (1996).

17) R. J. De. Young, J. Stripling, T. M. Enderson, D. H. Humes, W. T. Davis and E. J. Conway: Proc. Intersoc. Energy Convers. Eng. Conf. , Aug. 1984. p. 339.

18) R. J. De Young, G. H. Walker, M. D. Williams, G. L. Schuster and E. J. Conway: NASA TM-4002 (1987).
19) G. A. LANDIS, L. H. WESTERLUND, NASACR-190793 (1992).

20) M. Niino, K. Kisara and L. Chen: Space Power 12 (1993) 123.

21) P. E. Glaser: Science 162 (1968) 857.

22）材料科学技術振興財団，「月面エネルギー基 地構想の概念検討」平成6年度成果報告書 (1995年).

23) K. Eguchi, M. Niino, H. Arashi, Y. Takeda and T. Kobayashi: WPT-95 (Kobe, Japan Oct. 16-19, 1995).

24) H. W. Friedman: Proc. SPIE 2121 (1994) 232.

25) R. A. Lowe, G. A. Landis and P. Jenkins: IEEE Trans. Electron Devices, 42 (1995) 744.

26) R. K. Jain and G. A. Landis: Proc. SPIE 2121 (1994) 264.

\section{レーザーワード}

レーザー高度計（laser altimeter）

パルスレーザー光を上空から発射し，地表面からの反射光を検出し，レーザーパルスの往復時 間から高度を求める装置をいう。レーザーレーダーの一つの形体で，レーザー測距の特殊な応用 技術である。従来の航空機搭載のものから最近ではスペースシャトル等の宇宙飛翔体搭載のもの も開発され，米国NASAで実現されている。最近ではLD励起のNd:YAGレーザー(波長 $1.06 \mu \mathrm{m})$ でパルス幅5-10nsものが一般に用いられている。地表や海面の形状をグローバルに観測するトポ グラフィーのための最も有効な手段である。発射ビーム数を複数にして精度を上げたり，反射パ ルスのエコーのパターンから地表の形状をより精密に測定し, 樹木の高度分布等も求められる技 術も開発されてきている。

(有賀 規) 